\title{
Socjologia Ziem
}

\section{Zachodnich i Północnych -}

nowe paradygmaty

i wyzwania badawcze.

Refleksje na kanwie obrad

XVI Ogólnopolskiego Zjazdu

Socjologicznego w Gdańsku

\section{ANDRZEJ SAKSON}

Instytut Zachodni im. Zygmunta Wojciechowskiego w Poznaniu

DOI: https://doi.org/10.26774/rzz.183

$01 / 2017$

ROCZNIK

ZIEM

ZACHODNICH

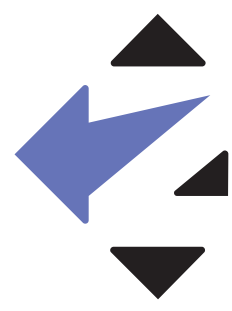


Przemiany dokonujące się w Polsce po 1989 r. skłoniły wielu socjologów do podjęcia nowych badań nad kształceniem tożsamości współczesnych mieszkańców kresów zachodnich i północnych Polski. Przedmiotem dyskusji stały się stare i nowe paradygmaty w badaniach Ziem Zachodnich i Północnych (ZZiP), jak również to, jaki typ zbiorowości lokalnych powstał na tym terenie. Wyjątkowa, prawie laboratoryjna możliwość śledzenia procesów społecznych na ZZiP absorbowała i absorbuje nadal wielu badaczy. Procesy społeczne tam zachodzące nie mają jednakowego kierunku i nie dają się jednakowo sklasyfikować. ZZiP i wchodzące w ich skład poszczególne regiony (Warmia i Mazury, Pomorze, Ziemia Lubuska, Dolny i Górny Śląsk) wykazywały i wykazują nadal własną specyfikę w porównaniu $\mathrm{z}$ innymi regionami kraju. Charakterystyczną cechą współczesnych badań socjologicznych na ZZiP jest zmiana dotychczasowych paradygmatów. W miejsce starych, np. „integracja ZZiP”, „społeczeństwo socjalistyczne”, powstały nowe, trafniej opisujące dokonujące się przemiany, np. „społeczeństwo postmigracyjne”, „integracja przestrzeni społecznej, wielokulturowość” lub też „społeczne tworzenie ojczyzn”. W refleksji nad przemianami tożsamości mieszkańców ZZiP pojawiły się różne podejścia do zbiorowości lokalnych. Są to hipotezy „wykorzenienia i alienacji” oraz „nowej jakości społecznej”, jak również koncepcja „słabych” i „mocnych” społeczności lokalnych.

W sprawie typów społeczności lokalnych na ZZiP formułowane są dwa sprzeczne sądy: pierwszy zwraca uwagę na wykorzenienie, atomizację społeczną i niski rozwój świadomości zbiorowej, drugi podkreśla wyższy poziom modernizacji, otwartości, proinnowacyjności i przedsiębiorczości.

Miejscem dyskusji nad wyzwaniami badawczymi stojącymi przed socjologią ZZiP są kolejne Zjazdy Socjologiczne. Na ostatnim z nich, który odbył się w Gdańsku w 2016 r., formułowano następujące pytania: Na czym polega specyfika procesów społecznych dokonujących się na obszarze ZZiP? Przed jakimi wyzwaniami badawczymi stoją przedstawiciele nauk społecznych prowadzący badania na ZZiP? Na ile uległy zmianie dotychczasowe paradygmaty badań o ZZiP? Czy pojawiły się nowe? Na czym polega ich istota? Czy wykształciła się tożsamość mieszkańców Ziem Zachodnich i Północnych? Czy uprawnione było założenie, że Kresowiacy, którzy wyrokami historii znaleźli się w miastach i metropoliach ZZiP, przejmą zdobycze poniemieckiej cywilizacji i staną się „czymś w rodzaju polskiej wersji Niemców”? Czy będąc mieszkańcem leżącego na „Zachodzie” Gdańska, Szczecina i Wrocławia, można być mentalnie przynależnym do Europy Wschodniej? Na czym polega istota społeczności postmigracyjnych na ZZiP? Jakie będą kierunki ich rozwoju?

To niektóre z wielu pytań, które były żywo dyskutowane podczas posiedzenia grupy G72: „Ziemie Zachodnie i Północne - pomiędzy integracją a dezintegracją” na XVI Ogólnopolskim Zjeździe Socjologicznym. Organizatorem tego spotkania było Polskie Towarzystwo Socjologiczne (PTS). Obrady pod hasłem Solidarność w czasie nieufności odbywały się w dniach 14-17 września 2016 r. w gościnnych progach Wydziału Nauk Społecznych Uniwersytetu Gdańskiego w Gdańsku-Wrzeszczu.

Władysław Markiewicz, dyrektor Instytutu Zachodniego w latach 1966-1973, gdzie po 1956 r. powstały zręby socjologii ZZiP, tak prezentował w Encyklopedii socjologii. Suplemencie (Warszawa 2005) zakres badawczy nowej subdyscypliny socjologii: 
Bezsprzecznie najważniejszym problemem praktycznym i poznawczym skłaniającym do badania Ziem Zachodnich były procesy przystosowania i integracji społecznej. Na kanwie tego problemu ukazało się wiele prac dotyczących zagadnień ogólniejszych, np. procesów narodowotwórczych.

[...] Autorzy zrazu chyba najaktywniej rozwijający socjologię Ziem Zachodnich, Zygmunt Dulczewski i Andrzej Kwilecki, walnie przyczynili się do tego, że pojęcia często używane także w innych dyscyplinach lub subdyscyplinach socjologicznych, takie jak integracja czy dezintegracja społeczna; przenikanie, zderzenie i upodobnianie się kultur; asymilacja, adaptacja i akulturacja; horyzontalna i wertykalna ruchliwość społeczna, zostały po raz pierwszy zdefiniowane z myślą o polskiej specyfice i w nauce polskiej upowszechnione ${ }^{1}$.

Spotkania i debaty socjologów zajmujących się problematyką ZZiP na zjazdach PTS mają długą tradycję. Ograniczę się do tych, w których uczestniczyłem. W 1986 r. w trudnych czasach zwiastujących upadek realnego socjalizmu odbył się VII Ogólnopolski Zjazd Socjologów we Wrocławiu. Otwierająca zjazd sesja plenarna zatytułowana była Ziemie Odzyskane - procesy integracji społecznej. Zapoczątkowane we Wrocławiu krytyczne debaty na temat paradygmatów badań ZZiP zaowocowały nie tylko pozjazdową publikacją pod redakcją Władysława Misiaka pt. Zachodnie i Północne Ziemie Polski z perspektywy badań socjologicznych (Wrocław 1990), ale także powstaniem w 1988 r. Niezależnego Ogólnopolskiego Zespołu Socjologów ds. Ludności Rodzimej, działającego przy Instytucie Zachodnim. Skupił on grono znanych później badaczy, którzy prowadzili liczne studia terenowe wśród społeczności Ślązaków, Kaszubów, Mazurów i Warmiaków oraz nad mniejszością niemiecką. Efektem tych badań były monografie i prace zbiorowe, ukazujące dramatyczne losy tych społeczności zamieszkujących ZZiP².

Na kolejnym, VIII Zjeździe Socjologów w Toruniu w 1990 r. Włodzimierz Durka analizował socjologiczne paradygmaty $w$ badaniach ZZiP. Zwracał uwagę m.in. na znaczenie paradygmatu integracji ${ }^{3}$, który stopniowo wypierany był przez paradygmat wielokulturowości, poniemieckości i pogranicza ${ }^{4}$.

Problematyka socjologii ZZiP była wyraziściej zaprezentowana na XIII Zjeździe PTS w Zielonej Górze w 2007 r., gdzie dyskutowano o przemianach społecznych

1 W. Markiewicz, [w:] Encyklopedia socjologii. Suplement, red. H. Kubiak [et al.], Warszawa 2005, s. 264.

2 Por. np.: Ślqzacy, Kaszubi, Mazurzy i Warmiacy - pomiędzy polskościq a niemieckościq, red. A. Sakson, Poznań 2008 (tamże obszerna literatura przedmiotu).

3 W. Durka, Czy istnieje socjologiczny paradygmat Ziem Zachodnich i Północnych, [w:] Przełom i wyzwanie. Pamiętnik VIII Zjazdu Socjologicznego, Warszawa-Toruń 1991.

4 Interesująca debata na temat przemian paradygmatu badawczego socjologii ZZiP toczyła się na łamach „Przeglądu Zachodniego” - czasopisma Instytutu Zachodniego. Por.: Czy i jak badać dzisiaj Ziemie Zachodnie i Północne Polski. W części pierwszej dyskusji swe spostrzeżenia opublikowali: Zygmunt Dulczewski, Krzysztof Kwaśniewski, Andrzej Kwilecki i Janusz Ziółkowski („Przegląd Zachodni”, nr 3 (1997), s. 1-13). W kolejnej części dyskusji głos zabrali: Bożena Domagała, Henryk Galus, Zbigniew Kurcz, Marek Latoszek, Tomasz Marciniak, Andrzej Sakson, Maria Szmeja, Anna Szyfer („Przegląd Zachodni”, nr 3 (1998), s. 3-480). Por. także: A. Sakson, Współczesne badania socjologiczne na Ziemiach Zachodnich i Północnych - stare i nowe wyzwania, [w:] Odmiany polskich tożsamości, red. K. Bondyra, S. Lisiecki, Poznań 2002, s. 75-88. 
w kontekście pogranicza, w tym przygranicza polsko-niemieckiego i polsko-kaliningradzkiego ${ }^{5}$. Kolejnym miastem ZZiP w którym odbył się Zjazd PTS był Szczecin. Podczas XV Zjazdu w 2013 r. obradowano w sekcji pod nazwą: „Ziemie Zachodnie i Północne w perspektywie regionalnej" ${ }^{\prime}$.

Niezależnie od spotkań socjologów zajmujących się problematyką ZZiP na kolejnych zjazdach PTS na uwagę zasługują konferencje i publikacje związane z jubileuszami przyłączenia ZZiP do państwa polskiego7. Problematyka ZZiP jest stałym elementem planów badawczych socjologów zamieszkujących na ZZiP, głównie w środowiskach uniwersyteckich Olsztyna, Gdańska, Szczecina, Zielonej Góry i Wrocławia8.

Na Ziemiach Zachodnich i Północnych dokonał się po 1945 r. niespotykany w dziejach nowożytnej Europy proces masowej wymiany ludności. W zasadniczy sposób zmieniły się dotychczasowe stosunki społeczno-polityczne, gospodarcze, wyznaniowe i narodowe. Dochodziło do zderzeń ideologii „zdobywców” i „przegranych”, „szabrowników” i „pionierów”. Dla wielu była to swoista ziemia przeklęta. Na niektórych obszarach lawinowo narastały krzywdy - jednostek, całych społeczności i grup narodowych. Zanikały kultury, wyjeżdżali i przybywali nowi ludzie, którzy przez długi czas byli sobie obcy.

Na ówczesny „Zachód” jechali ci, którzy musieli szukać nowego miejsca na ziemi, bo stare na „Wschodzie” znalazło się niespodziewanie poza granicami Polski, lub ci, którzy przybywali tu ze zmienionymi nazwiskami i nowymi życiorysami. Byli także ci, którzy widzieli tu szansę powetowania sobie lat wojny, z której wyszli pozbawieni wszystkiego, prócz życia. Ci, którzy uwierzyli w misję zagospodarowania tych ziem, oraz ci, którzy traktowali Ziemie Odzyskane jako pozbawiony właścicieli skarbiec.

Wybitny polski socjolog Jan Szczepański charakteryzując w 1989 r. procesy społeczne dokonujące się na Ziemiach Zachodnich i Północnych Polski, pisał, iż tworzące się tam społeczności lokalne „były emanacją społeczeństwa polskiego, odbijały zdolności tego społeczeństwa do rozwiązywania nowych zadań wynikających z sytuacji niezwykłych i nieznanych w tradycyjnym sposobie życia. Stąd uważam, że zasiedlenie tych ziem było testem wartości społeczeństwa polskiego"9.

Nestor polskich demografów Edward Rosset tak pisał o niepowtarzalności i doniosłości procesów społecznych dokonujących się na ZZiP, które określał mianem laboratorium demograficznego: ska, M. S. Szczepański, Ż. Stasieniuk, Warszawa 2016, s. 271-384.

7 Por. m.in.: Ziemie Zachodnie i Północne Polski w półwieczu 1945-1995, Toruń 1997; Pomorze - trudna Ojczyzna? Kształtowanie się nowej tożsamości 1945-1995, red. A. Sakson, Poznań 1996; Demografia i społeczeństwo Ziem Zachodnich i Północnych 1945-1995. Próba bilansu, red. E. Frątczak, Z. Strzelecki, Warszawa 1996; Ziemie Odzyskane/Ziemie Zachodnie i Północne 1945-2005. 60 lat w granicach państwa polskiego, red. A. Sakson, Poznań 2006.

8 Polskie Ziemie Zachodnie. Studia socjologiczne, red. A. Michalak, A. Sakson, Ż. Stasieniuk, Poznań 2011.

9 J. Szczepański, Przedmowa, [w:] A. Sakson, Mazurzy - społeczność pogranicza, Poznań 1990, s. XIV. 
[...] wypadki dziejowe, związane z II wojną światową wzbogaciły polską a zarazem i światową fenomenologię demograficzną o zdarzenia niezwykłe i niepowtarzalne. Za takie można uważać: niemal całkowitą wymianę ludności na obszarach, które po wielu wiekach obcego panowania powróciły do macierzy; ukonstytuowanie się na tych terenach ludności o niespotykanym profilu wieku, mianowicie ludności wyjątkowo młodej; niezwykłe ożywienie demograficzne, jakiego widownią stały się te tereny po ich zasiedleniu przez ludność polską. Tereny, o których tu mowa - a są nimi nasze ziemie zachodnie i północne - urastają dzięki podanym faktom do roli laboratorium demograficznego ${ }^{10}$.

Zasadniczy proces kształtowania się struktury ludnościowej na ZZiP przypada na lata 1945-1950. Charakteryzują go niespotykane, wielkie ruchy wędrówkowe, wysiedlenie ludności niemieckiej oraz napływ ludności polskiej. W 1950 r. po prawie całkowitym wysiedleniu ludności niemieckiej na obszarze ZZiP mieszkało ogółem 5 894,6 tys. ludności, w tym 1 165,0 tys. zweryfikowanej ludności autochtonicznej (rodzimej, tutejszej), co stanowiło 19,6\% ogółu ludności Ziem Odzyskanych. W latach 1946-1985 nastąpił wzrost liczby mieszkańców ZZiP z 5 mln w 1946 r., 6967 tys. w 1955 r., 8351 tys. w 1965 r., 9059 tys. w 1975 r. do 10306 tys. w 1995 r.

W 2002 r. liczba ludności ZZiP wynosiła 10237 tys. ${ }^{11}$ Wraz z upływem lat następowało stopniowe upodabnianie się struktury demograficznej ZZiP do wskaźników ogólnopolskich (struktura wiekowa ludności, przyrost naturalny, dzietność kobiet, procesy depopulacji, skala migracji itp.).

Na specyfikę ZZiP w porównaniu z ziemiami dawnymi Polski oraz na zróżnicowanie międzyregionalne w obrębie Ziem Odzyskanych istotnie wpłynęły skład i proporcje pomiędzy różnymi grupami ludności, które po 1945 r. zetknęły się na tym obszarze.

Zachodzące po 1945 r. na Ziemiach Zachodnich i Północnych procesy społeczne charakteryzują się intensywnością i złożonością. Jest to rezultat - z jednej strony bardzo skomplikowanej sytuacji politycznej, gospodarczej i demograficznej na tych obszarach, z drugiej zaś - zderzenia kultur, wynikającego z zetknięcia się tu wielu grup ludności o różnym pochodzeniu regionalnym, o odmiennym bagażu kulturowym i cywilizacyjnym, zróżnicowanym poczuciu narodowym, różnorakim wyznaniu oraz motywie przybycia na te ziemie.

Obszar Ziem Zachodnich i Północnych zamieszkiwało sześć głównych kategorii ludności:

1. Dawni mieszkańcy obszarów III Rzeszy, tj. Prus Wschodnich i Zachodnich, Pomorza, Ziemi Lubuskiej i Śląska, tj. ludność autochtoniczna oraz Niemcy, co stanowiło około jednej piątej (19,6\%) ogółu ludności tych ziem w 1950 r.

10 E. Rosset, Ziemie Zachodnie i Północne jako laboratorium demograficzne, „Studia Demograficzne”, z. 20 (1969), s. 3-4.

11 S. Wierzchosławski, Ludność Ziem Zachodnich i Północnych w świetle Narodowego Spisu Powszechnego 2002, [w:] Ziemie Odzyskane/Ziemie Zachodnie..., s. 81. 
2. Osadnicy (przesiedleńcy) z ziem dawnych (centralnej) Polski, stanowiący najliczniejszą kategorię ludności, która napływała na ZZiP. Ludność ta liczyła w 1950 r. 2 916,5 tys. osób, co stanowiło prawie połowę ludności (49,1\%) ZZiP.

3. Repatrianci (wysiedleńcy) z Kresów Wschodnich II Rzeczypospolitej, którzy w dwu falach (1945-1950 oraz 1956-1959) napływali na ZZiP. W 1950 r. ludność ta liczyła 1 331,9 osób, a po zakończeniu akcji przesiedleńczej w 1959 r. - ponad 1,7 mln osób, co stanowiło ok. 30\% mieszkańców ZZiP.

4. Reemigranci z Francji i Belgii oraz Rumunii i Jugosławii, a także z innych państw europejskich. W 1950 r. liczyli oni 234,7 tys. osób.

5. Ludność ukraińska i żydowska oraz przedstawiciele innych mniejszości narodowych i etnicznych. Po zakończeniu akcji „Wisła”, której celem było wysiedlenie ludności ukraińskiej z Polski południowo-wschodniej, na ZZiP w 1947 r. znalazło się 137 tys. Ukraińców i Łemków. W okresie bezpośrednio powojennym (1945-1947) na Ziemiach Odzyskanych mieszkało ok. 150 tys. ludności żydowskiej. Zamieszkiwało tu także ok. 10 tys. Greków i Macedończyków oraz ok. 20 tys. Romów.

6. Odrębną społeczność stanowiły wojska radzieckie stacjonujące do $1993 \mathrm{r}$. w Polsce. Około 90\% tych wojsk, liczących wraz z cywilami 100-150 tys. osób, stacjonowało w zachodniej Polsce (ogółem przewinęło się ich przez Polskę, razem z rodzinami ponad $3 \mathrm{mln}$ ).

Kształtujące się społeczności lokalne nie były kontynuatorami regionalnych kultur przywiezionych przez poszczególne grupy ludności napływowej. Pod tym względem stanowią one konglomerat różnych regionalnych kultur.

W efekcie ogólnej analizy procesów społecznych, mających miejsce w ciągu ostatnich siedemdziesięciu lat na Ziemiach Zachodnich i Północnych należy stwierdzić, iż wykazują one odmienną specyfikę i szczególną dynamikę w porównaniu z innymi regionami kraju. Charakterystyczną ich cechą jest to, iż na przestrzeni dziesięcioleci dokonała się głęboka integracja tych ziem ze społeczeństwem ogólnopolskim. Dotyczy to zarówno płaszczyzny politycznej, społecznej, gospodarczej, językowej, wyznaniowej, jak i świadomościowej. Ziemie Zachodnie i Północne postrzegane są przez ich mieszkańców oraz ogół Polaków jako integralna część kraju, która posiada odrębny koloryt i specyfikę, podobnie jak różnią się od siebie regiony Podhala i Mazowsza, Wielkopolski i Podlasia, tak odrębności mają Pomorze oraz Warmia i Mazury czy Śląsk.

Organizatorzy i prowadzący sympozjum o ZZiP w ramach gdańskiego Zjazdu PTS: Stefan Marcinkiewicz, Jacek Poniedziałek, Karolina Ciecierska-Kulesza oraz Andrzej Sakson, w założeniach dotyczących prac sekcji zwrócili uwagę, że: „Przesunięcie terytorium na zachód wiązało się również z rozpoczęciem wielkiego społecznego eksperymentu budowania polskich Ziem Zachodnich i Północnych, który trwa do dziś".

Obszary tematyczne obrad określono następująco:

- tworzenie się nowych społeczności lokalnych i regionalnych;

- nowe tożsamości lokalne i regionalne;

- nowe lokalizmy i regionalizmy;

- integracja społeczna i ekonomiczna regionów Ziem Zachodnich i Północnych,

w wymiarze wewnętrznym oraz zewnętrznym; 
- problematyka ludności autochtonicznej od roku 1945.

Wśród wielu zagadnień poruszanych podczas gdańskiego spotkania kilka kwestii wzbudziło szczególne zainteresowanie. Autor tego opracowania w wystąpieniu wprowadzającym do obrad sesji zwrócił uwagę na postmigracyjny charakter ZZiP. W tym kontekście przedstawił po raz pierwszy w tym gronie koncepcję czwartej generacji mieszkańców tych ziem.

Pierwsza generacja to osoby $\mathrm{w}$ różnym wieku, które $\mathrm{w}$ latach powojennych zasiedlały ZZiP. Drugie pokolenie tworzą osoby, które urodziły się na ZZiP w okresie powojennym. Stanowią one tym samym pierwsze pokolenie urodzone na Ziemiach Nowych. Osoby urodzone tu w latach 1945-1970 żyły w cieniu wojennych zniszczeń i powojennej traumy kulturowej. Dla tego i kolejnego pokolenia, urodzonego w latach 1971-1996 "na Zachodzie” jego krajobraz, typ zabudowy oraz „cała ta poniemieckość” były czymś naturalnym, oswojonym i „własnym” miejscem do życia. Nie oznacza to jednak, że nieobca im była atmosfera poczucia pewnej tymczasowości i „zawieszenia tożsamościowego” wynikającego m.in. z niemieckich postulatów rewindykacyjnych docierających do mieszkańców tych ziem.

Odrębność czwartego pokolenia, tzn. trzeciej generacji osób urodzonych na ZZiP już po 1996 r., opiera się na koncepcji „postnowoczesnego pokolenia”, w istotny sposób nieobciążonego bagażem przeszłości, którego większy lub mniejszy ciężar kładł się ciężarem na barkach ich rodziców, dziadków i pradziadków. Pokolenie to, socjalizowane i wychowywane w postnowoczesnej i zglobalizowanej rzeczywistości społecznej i gospodarczej, pozbawione jest nie tylko garbu przeszłości, ale nie różni się od ogółu mieszkańców kraju i kontynentu. W przypadku czwartego pokolenia mamy do czynienia z zespoleniem obiektywnego i subiektywnego poczucia tożsamości miejsca. To fenomen czwartego pokolenia wyznaczać będzie nowe kierunki przemian społecznych i tożsamościowych w najbliższej przyszłości.

Wojciech Łukowski w wystąpieniu noszącym tytuł „Po integracji” Ziem Zachodnich i Północnych: Semiotyka odzyskanych krajobrazów zwrócił uwagę, iż na ZZiP mamy obecnie do czynienia ze stanem, który można określić jako stan właśnie „po integracji”. Jego zdaniem definitywnie wygasła realizacja projektu określanego mianem integracji Ziem Zachodnich i Północnych z Macierzą. Nie zakończył się jednak bynajmniej proces wypełniania tego tworu „po integracji” narracjami czy uzasadnieniami, nadającymi mu sens, podsuwającymi mu kulturową podstawę istnienia. Od przełomu 1989/1990 r. w czasoprzestrzeni Ziem Zachodnich i Północnych pojawiają się „pointegracyjne” zróżnicowane propozycje, sposoby pisania historii, wizje czy nawet utopie.

Koncepcja integracji Ziem Zachodnich i Północnych zawierała w sobie rodzaj obietnicy przyłączenia, narodowego i terytorialnego włączenia ZZiP. Po roku 1989/1990 te ziemie, jeszcze do niedawna Ziemie Zachodnie i Północne, muszą radzić sobie już $\mathrm{w}$ wymiarze symbolicznym same, bez centralnie generowanego projektu. Innymi słowy, na terenach zwanych jeszcze do niedawna Ziemiami Zachodnimi i Północnymi możliwe jest nadal sięganie po oferty symboliczne formułowane $\mathrm{w}$ polskim centrum, czy także po oferty, pochodzące z innym źródeł o bardziej uniwersalnym charakterze, wreszcie na znaczeniu zyskują projekty zakładające endogeniczność. 
Oferty te zresztą często się przenikają, wzmacniają, posiłkują, czasami wchodzą w kolizję. Konstruują warstwy czasu i mogą być uznawane za odrębną niejednorodną semiosferę, w obrębie której zachodzą procesy innowacyjne.

Łukowski zwrócił także uwagę m.in. na proces wypłukiwania specyficznych regionalnych i lokalnych treści symbolicznych i semiotycznych. Zjawisko to zaistniało np. w Pieniężnie, gdzie miał miejsce konflikt społeczny dotyczący domeny symbolicznej związanej z upamiętnieniem poległego pod tym miastem generała Armii Czerwonej Iwana Czerniachowskiego. Przeciwieństwem tego typu destruktywnych działań jest tworzenie własnej lokalnej czasoprzestrzeni bazującej na przekonaniu, iż nasze miejsce zamieszkania jest czymś wyjątkowym, zarówno w wymiarze lokalno-regionalnym, jak i uniwersalnym. Interesującą ilustracją tego zjawiska jest twórczość literacka i dziennikarska Marka S. Darskiego. W ten nurt refleksji „po integracji" wpisują się także nowe propozycje wypełniania sensu społecznego w społecznościach lokalnych, które mogą zmierzać do utwierdzania przekonania, iż dana społeczność żyje na „tyłach historii” i skazana jest na dalszą marginalizację i peryferyjność. Przeciwieństwem tego sposobu myślenia może być dążność do bycia liderem nowoczesności. Taka sytuacja ma miejsce np. w Gołdapi, gdzie burmistrz tego leżącego na pograniczu polsko-kaliningradzkiego miasta głosił hasło, iż: „Prawo do życia jest ważniejsze niż prawo celne”, tzn. żeby przeżyć, należy łamać zasady celne przy przekraczaniu granicy w celach zarobkowych („mrówkowanie”).

Na znaczenie traumy kulturowej w opisie procesów społecznych na ZZiP zwrócił uwagę Stefan Marcinkiewicz w wystąpieniu pt. Traumy dezintegracji i reintegracji w wymiarze lokalnym na przykładzie Ełku i okolic. Trauma jest efektem wielkiej przemiany, w tym szeroko rozumianych procesów dezintegracji i reintegracji. Piotr Sztompka zaproponował analizę zmian społecznych jako traumy kulturowej. Koncepcja ta nadaje się do opisu zmian nagłych, szerokich, radykalnych i szokujących. Z taką zmianą mieliśmy niewątpliwie do czynienia w 1945 r. na Ziemiach Odzyskanych. Koniec II wojny światowej i powojenne przesunięcia granic skutkowały rewolucją społeczno-kulturową. Przymusowe czy dobrowolne przemieszczenia mas ludzi prowadziły do rozpadu dotychczasowych struktur społecznych: rodzin, sąsiedztw i całych społeczności lokalnych (wsi, dzielnic, miast). Przestrzeń wyniszczona przez wojnę została zasiedlona przez nowych ludzi reprezentujących inne kultury, którzy zostali zmuszeni do reintegracji. W sensie społeczno-kulturowym niemieckie miasta i wsie przestały istnieć. W większości zastąpiły je polskie odpowiedniki. Zamieszkanie w nowym pejzażu kulturowym wymagało od ludzi odporności psychicznej, co nie ułatwiały powojenne zagrożenia. Relacje między ludźmi pochodzącymi z różnych rejonów dawnej Rzeczpospolitej i pozostałą ludnością miejscową układały się różnie. Narzucony odgórnie ustrój polityczny wywoływał poczucie niepewności. Nadzieja na powrót w rodzinne strony i obawa przed powrotem dawnych mieszkańców spowalniały integrację. Jednak w większości przypadków integracja przebiegła bez większych przeszkód, a dawni osadnicy odnaleźli swoją "nową ojczyznę” na Ziemiach Zachodnich i Północnych. Przez cały okres powojenny ubywało natomiast dawnych mieszkańców tych ziem, którzy wykorzystywali kolejne kryzysy społeczno-polityczne, aby opuścić Polskę. 
Traumy dezintegracji i reintegracji, z którymi musieli się zmierzyć nowi mieszkańcy ZZiP, to problemy rozpadu grupy, z której się wywodzili, często dramatyczne i tragiczne doświadczenia z okresu wojny i okupacji z lat 1939-1945, trauma wędrówki i wyboru nowego miejsca zamieszkania oraz budowanie nowej tożsamości miejsca, które często opierało się na negacji, a później pogodzeniu się z poniemieckością.

Tworzeniu postmigracyjnej tożsamości poświęcone było wystąpienie Karoliny Ciechorskiej-Kuleszy, Jacka Poniedziałka oraz Aleksandry Paprot. Ciechorska-Kulesza w wystąpieniu zatytułowanym Wokół miejsca. Integracja i tożsamość mieszkańców Ziem Północnych oczami liderów skupiła swą uwagę na mieszkańcach ziemi elbląskiej. Region ten, o słabo wykształconej odrębności, cechuje niestabilność granic administracyjnych i liczne zmiany struktur władzy lokalnej, będące znaczącym elementem skomplikowanych procesów „wrastania” i „bycia u siebie”. Na podstawie własnych badań empirycznych, opartych głównie na wywiadach z lokalnymi liderami, ukazała elementy składające się na kształtowanie tożsamości miejsca. Specyfika miejsca wpływa na zbiorowość, jej przekształcenia, a także stopień integracji i aktywność społeczną mieszkańców. Na fundamencie tożsamości miejsca budowana jest „współczesna” tożsamość, która ma zapełnić „pustą przestrzeń” po $1945 \mathrm{r}$. Pojęcie miejsca pozwala także uniknąć problematyczności nazywania owej przestrzeni w kategoriach regionalnych i lokalnych, wynikających ze „sztuczności” i „nienaturalności" regionu i poszczególnych subregionów (Powiśla, Warmii i Żuław). Choć „tożsamość miejsca” skupiona jest głównie wokół przestrzeni, to znaczące okazuje się także jej odnoszenie do konkretnych cech społeczności i mieszkańców, również tych z przeszłości. Próbując nazywać i opisywać tożsamości przestrzenne, liderzy podkreślają ich związek ze stopniem integracji zbiorowości, na co wpływ mają powojenne losy ludności, w tym „stopień postmigracyjności” (struktura i udział ludności napływowej w stosunku do ludności rodzimej, kierunki migracji etc). „Tylko” miejsce staje się powoli dla mieszkańców „aż” miejscem, co przejawia się w podkreślaniu nie tyle wyjątkowości samej przestrzeni, ile komponentu emocjonalnego, a jeszcze bardziej działaniowego, przejawiającego się w aktywności społecznej.

Jacek Poniedziałek w wystąpieniu pn. Rekonstruowanie pruskości. Próby tworzenia nowych tożsamości w oparciu o odtwarzane dziedzictwo najdawniejszych mieszkańców Warmii, Mazur i Powiśla zwrócił uwagę na poszukiwania tożsamości po 1989 r. wśród mieszkańców ZZiP. Powodowały one jednak stan pewnej niedookreśloności. Skutkowało to potrzebą poszukiwania własnych form tożsamościowego zakotwiczenia w regionie zamieszkania.

Jedną z takich prób jest odwołanie się do dziedzictwa bałtyjskich Prusów. W regionie od co najmniej lat dwudziestu zaobserwować można rosnące zainteresowanie pruskim dziedzictwem kulturowym. Formalne organizacje lub niesformalizowane inicjatywy grupują osoby, które podjęły się „aktywności tożsamościotwórczej”. Tym zaś, co może jednoczyć ludzi należących do różnych grup narodowościowych, etnicznych, religijnych czy regionalnych i okazuje się najmniej problematyczne, jest dziedzictwo plemion pruskich. Zbudowana na dziedzictwie kulturowym Prusów tożsamość regionalna ma integrować mieszkańców regionu, którzy pochodząc z różnych grup (autochtonów, Ukraińców, potomków przesiedleńców z Wileńszczyzny 
czy osadników z tzw. Polski Centralnej), różnie interpretują przeszłość, z różnymi kulturami się utożsamiają, co prowadzić może do konfliktów i dezintegracji społecznej. Wspominane inicjatywy to: Towarzystwo Pruthenia, Stowarzyszenie Prusów w Polsce Prusapira, inicjatywa Prusai i Związek Prusów w Polsce.

Aleksandra Paprot przedstawiła wyniki własnych badań terenowych nad kształtowaniem się tożsamości lokalnych i regionalnych na Żuławach i Powiślu. Autorka ukazała kierunki rozwoju współczesnego ruchu regionalnego i lokalnego oraz opisała realny wpływ różnego typu instytucji na otoczenie społeczne, w tym na kształtowanie się tożsamości miejsca.

Kolejny blok zagadnień dotyczył dynamiki przemian narodowościowych na ZZiP. Maria Szmeja w wystąpieniu zatytułowanym Adaptacja? Asymilacja czy wykluczenie? Ślqzacy w państwie polskim zwróciła uwagę, że działania liderów grupy śląskiej skoncentrowane są na utrzymaniu podmiotowości grupy w kraju i regionie. Z jednej strony domagają się statusu mniejszości etnicznej, z drugiej zabiegają o autonomię regionu. Działania podejmowane przez liderów zaowocowały większą otwartością w wyrażaniu tożsamości śląskiej (wyniki spisu z 2002 i 2011 r.) oraz w powszechnym artykułowaniu niezadowolenia z pozycji w państwie polskim. Widoczne jest, że Ślązacy nie zasymilowali się ze społeczeństwem polskim, a żyjąc w nim od paru pokoleń, podkreślają różnice kulturowe. Nie wstydzą się odmiennej kultury i przeszłości. Nie chcą być zdominowani, a przymus polonizacyjny odbierają jako nacisk grupy dominującej. Rodzi się pytanie: dlaczego tak silnie podkreślają odrębność od narodu polskiego? Co sprawia, że czują się wykluczeni z niego i nie dążą do asymilacji? Kto ponosi odpowiedzialność za ten stan: Polacy swoim brakiem zaufania do mniejszości, chęcią dominacji, narzucaniem standardu kulturowego? Czy może sama grupa śląska, której liderzy nie potrafią rozmawiać z przedstawicielami grupy dominującej i realizują doraźną politykę?

Teresa Sołdra-Gwiżdż w wystąpieniu Socjologiczne oglq̨dy Ślq̨ska - dominujqce perspektywy badawcze postawiła tezę o odmiennych sposobach postrzegania Śląska. Jedna z nich to wizja rodowitych Ślązaków, druga to postrzeganie Śląska jako piastowskiej dzielnicy Polski. W socjologicznych oglądach Śląska dominuje styl myślowy (przymus myślowy), który można określić mianem śląskich krzywd lub śląskiej krzywdy, wyłączający z tego uniwersum krzywdy dziejowe ludności przesiedlonej z Kresów Wschodnich oraz inne grupy ludności napływowej, przede wszystkim Łemków i Ukraińców, którzy zostali przymusowo osiedleni na Dolnym Śląsku w wyniku akcji „Wisła”, ale można także wskazać inne szczątkowe w tej chwili grupy: Żydów, Karaimów, Białorusinów, a nawet diasporę grecką. Z takiego stylu myślowego wypływa socjologiczny obraz Śląska jako wewnętrznej kolonii, obszaru rabowanego i wykorzystywanego zarówno przez Niemcy, jak i Polskę. Pojęcie i poczucie krzywdy śląskiej martyrologii generuje z kolei kompleks odwróconych pleców, akcentujący małe zainteresowanie śląskim sprawami, upośledzenie, brak podmiotowości i bierność Śląska.

Irena Kurasz w referacie zatytułowanym Niemcy wczoraj i dziś. Przyczynek do analizy przemian społeczno-kulturowych ludności niemieckiej Dolnego Ślqska od roku 1945 do współczesności omówiła położenie diasporycznej i niewielkiej liczebnie 
mniejszości. Aleksandra Herman przedstawiła rolę kobiet w kreowaniu ciągłości kulturowej mniejszości ukraińskiej o korzeniach wysiedleńczych mieszkających od 1947 r. na ZZiP. Część referatową sympozjum zamykało wystąpienie Sebastiana Kołodziejczaka na temat aspiracji życiowych i zawodowych studentów szczecińskich uczelni, stojących u progu kariery zawodowej.

W trakcie ożywionej dyskusji Zbigniew Kurcz zwrócił uwagę na ewolucję paradygmatów w badaniach nad ZZiP. Bliżej scharakteryzował specyfikę nowego paradygmatu pogranicza. Andrzej Sadowski podkreślił potrzebę dostrzegania zróżnicowań regionalnych w obrębie ZZiP. Wyróżnić tam można, podobnie jak w obszarze całej Polski, społeczności lokalne o różnym stopniu zintegrowania. Inspirujące wystąpienia oraz ożywiona dyskusja wywołały pytanie dotyczące sensu powołania, w strukturach PTS, nowej sekcji dotyczącej socjologii ZZiP. Stworzyłaby ona instytucjonalną platformę do prezentacji najnowszych wyników badań oraz doskonalenia warsztatu teoretycznego i metodologicznego.

Organizatorzy spotkania planują publikację tekstów w renomowanej serii wydawniczej, ukazującej się od 1957 r. w Instytucie Zachodnim, a noszącej tytuł: Ziemie zachodnie. Studia i materiały. Dotychczas ukazało się 27 monografii i prac zbiorowych poświęconych różnym aspektom przemian społecznych i kulturowych na ZZiP. Inną rozważaną możliwością jest publikacja na łamach szczecińskiego czasopisma „Opuscula Sociologica”. 


\section{Bibliografia}

Encyklopedia socjologii. Suplement, red. H. Kubiak [et al.], Warszawa 2005

Odmiany polskich tożsamości, red. K. Bondyra, S. Lisiecki, Poznań 2002

Polskie transgranicza, red. Z. Kurcz, A. Sakson, Wrocław 2009

Polskie Ziemie Zachodnie. Studia socjologiczne, red. A. Michalak, A. Sakson, Ż. Stasieniuk, Poznań 2011

Pomorze - trudna Ojczyzna? Kształtowanie się nowej tożsamości 1945-1995, red. A. Sakson, Poznań 1996

Przełom i wyzwanie. Pamiętnik VIII Zjazdu Socjologicznego, Warszawa-Toruń 1991

Rosset E., Ziemie Zachodnie i Północne jako laboratorium demograficzne, „Studia Demograficzne”, z. 20 (1969)

Sakson A., Mazurzy - społeczność pogranicza, Poznań 1990

Sakson A., Współczesne badania socjologiczne na Ziemiach Zachodnich i Północnych - stare i nowe wyzwania, [w:] Odmiany polskich tożsamości, red. K. Bondyra, S. Lisiecki, Poznań 2002, s. 75-88

Ślqzacy, Kaszubi, Mazurzy i Warmiacy - pomiędzy polskościq a niemieckościq, red. A. Sakson, Poznań 2008

Wierzchosławski S., Ludność Ziem Zachodnich i Północnych w świetle Narodowego Spisu Powszechnego 2002, [w:] Ziemie Odzyskane/Ziemie Zachodnie i Północne 1945-2005. 60 lat w granicach państwa polskiego, red. A. Sakson, Poznań 2006

Ziemie Odzyskane/Ziemie Zachodnie i Północne 1945-2005. 60 lat w granicach państwa polskiego, red. A. Sakson, Poznań 2006

Ziemie Zachodnie i Północne Polski w półwieczu 1945-1995, red. R. Rybiński, Toruń 1997 


\section{Socjologia Ziem Zachodnich i Północnych - nowe paradygmaty i wyzwania badawcze. Refleksje na kanwie obrad XVI Ogólnopolskiego Zjazdu Socjologicznego w Gdańsku}

Streszczenie: Artykuł stanowi zarys rozwoju badań nad zagadnieniem socjologii Ziem Zachodnich i Północnych. Autor prezentuje dyskusje odbywające się na ten temat od kilku lat na forum Polskiego Towarzystwa Socjologicznego. Zwraca przy tym uwagę na nowe paradygmaty badawcze (jak „społeczeństwo postmigracyjne”, „integracja przestrzeni społecznej” etc.), które zastępują tematy charakterystyczne dla badań wcześniejszych (jak „integracja Ziem Zachodnich i Północnych”).

\section{Sociology of the Western and Northern Territories - new paradigms and research challenges. Reflections on the proceedings of the XVI All-Poland Sociology Congress in Gdańsk}

Abstract: The article presents an overview of the development of research on the issue of the sociology of the Western and Northern Territories. The author describes the discussions taking place on this topic for many years on the forum of the Polish Sociological Association. He draws attention to the new research paradigms (such as „postmigration society”, „integration within the social space” etc) which has replaced themes which were characteristic of earlier research (such as „integration of the Western and Northern Territories").

Słowa kluczowe: Ziemie Zachodnie i Północne, badania socjologiczne, tożsamość miejsca, Polskie Towarzystwo Socjologiczne

Key words: Western and Northern Territories, sociological research, identity of place, Polish Sociological Association 